\title{
ANALISA EKSPERIMENTAL MODULUS ELASTISITAS BAHAN KOMPOSIT GLASS FIBER REINFORCED PLASTIC (GFRP) BERDASARKAN VARIASI DIAMETER SERAT AKIBAT BEBAN IMPAK LAJU REGANGAN TINGGI
}

\section{EXPERIMENTAL ANALYSIS OF MODULUS ELASTICITY GLASS REALFORMED REINFORCED PLASTIC (GFRP) FIBER COMPOSITE BASED ON DIAMETER FIBER VARIOUS DUE TO LOAD IMPACT HIGH SPEED}

\author{
Zulfikar * \\ Mahasiswa Magister Teknik Mesin USU \\ *Coresponding Email:
}

\section{Abstrak}

Komposit GFRP merupakan salah satu bahan alternatif yang paling umum sebagai pengganti logam. Bahan ini memiliki bobot yang ringan, bentuk yang mudah, kekuatan yang baik, dan biaya produksi yang relatif lebih murah. Penelitian ini bertujuan untuk menyelidiki pengaruh variasi diameter serat dari perilaku mekanik, khususnya pada beban laju regangan yang berdampak tinggi. Penerapan teori momentum impuls di kawasan elastis adalah ilmu dasar untuk kasus ini. Peralatan AGC adalah peralatan yang digunakan untuk tes ini karena dapat menghasilkan laju gelombang regangan tinggi dalam pemuatan arah tunggal. Spesimen ditempatkan pada posisi ujung yang rapat di ujung bar input. Hasilnya menunjukkan bahwa peningkatan variasi diameter serat mempengaruhi nilai $\mathrm{E}$ yang dihasilkan. Dengan demikian, itu adalah rekomendasi untuk penggunaan bahan ini dalam keadaan tertentu.

Kata Kunci: Komposit GFRP, Modulus Elastisitas, Tegangan Tinggi

\begin{abstract}
GFRP composite is one of the alternative materials that the most common as a replacement for metal. This material has a light weight, easy to shape, good strength, and the production cost is relatively cheaper. This study aims to investigate the effects of fiber diameter variation of mechanical behavior, particularly on the load of high strain rate impact. The application of impulse momentum theory in the elastic region is the basic science for this case. The AGC apparatus is equipment that used for this test because it could generate the high strain wave rate in the single direction loading. Specimen is placed in the position of tight end against the end of the input bar. The results showed that the increase in fiber diameter variations affect the value of $E$ that is produced. Thus, it is become a recommendation for the use of this material in certain circumstances.
\end{abstract}

Keywords: GFRP Composite, Elasticity Modulus, High Strain Rate Impact 
Zulfikar, Analisa Eksperimental Modulus Elastisitas Bahan Komposit Glass Fiber Reinforced Plastic (Gfrp) ...

How To Cite: Zulfikar (2017). Analisa Eksperimental Modulus Elastisitas Bahan Komposit Glass Fiber Reinforced Plastic (Gfrp) Berdasarkan Variasi Diameter Serat Akibat Beban Impak Laju Regangan Tinggi. Jmemme (Journal Of Mechanical Engineering, Manufactures, Materials And Energy). 1 (2): 47-56 


\section{PENDAHULUAN}

Komposit GFRP merupakan salah satu bahan alternatif sebagai pengganti bahan logam. Bahan ini memiliki bobot yang ringan, mudah dibentuk, kekuatan yang baik, serta biaya produksi yang relatif lebih murah. Namun data-data pengujian bahan ini masih sangat minim, terutama pada pengujian dinamik impak pada kondisi laju regangan tinggi. Seperti contoh pada bamper mobil dimana ratarata digunakan pada kecepatan tinggi dan segala cuaca. Oleh karena itu peneliti memandang perlu melakukan pengujian bahan ini pada kondisi dinamik..

Struktur komposit ialah struktur yang terdiri dari dua atau lebih bahan yang memiliki perbedaan secara makroskopis yang digabungkan menjadi satu. Hasilnya ialah sebuah struktur baru dengan sifatsifat mekanik yang mewakili bahan penyusun.

Komposit GFRP tersusun dari polister resin sebagai matriks dan serat kaca sebagai penguatnya. Bahan ini pada umumnya dipergunakan untuk peralatan rumah tangga dan panel-panel listrik. Akan tetapi penggunaan bahan ini untuk bagianbagian permesinan masih sangat sedikit sekali karena belum intensif-nya penelitian dan pengembangan bahan untuk bidang permesinan.
Matriks polister resin yang digunakan ialah jenis diester tak jenuh. Sifat mekanik bahan ini mampu menyerap dan menyebarkan beban yang diberikan sama rata di semua arah. Hal ini menyebabkan bahan ini dapat meredam beban yang diberikan yang sangat baik. Modulus elastisitas bahan ini sendiri ialah berkisar antara 2 s.d. $4 \mathrm{GPa}$.

Serat kaca yang digunakan sebagai penguat merupakan bahan olahan dengan bahan dasar silica $\left(\mathrm{SiO}_{2}\right)$ dan penambahan oksida-oksida alkali serta logam. Sifat mekanik yang umumnya dimiliki oleh bahan ini ialah kaku, kuat, namun getas. Selain itu bahan ini pada umumnya memiliki ketahanan terhadap suhu yang tinggi dengan koefisien thermal explosion yang merata.

Metode yang digunakan dalam penelitian ini ialah metode impak laju regangan tinggi. Metode ini memiliki cara kerja berdasarkan teori penangkapan rambatan gelombang regangan yang terjadi dalam spesimen uji akibat pemberian beban impak kecepatan tinggi. Data awal diperoleh melalui susunan sensor penangkap regangan, atau dikenal dengan strain gage. Melalui sistim pengubah dan penguat arus, dan sistim pengubah transient, maka data regangan akan diperoleh. 
Tujuan penelitian ini ialah untuk mendapatkan harga modulus elastisitas E rata-rata bahan komposit GFRP dengan variasi diameter serat kaca akibat beban impak laju regangan tinggi.

\section{Sifat Elastis Komposit GFRP}

Struktur lamina komposit yang didalamnya terkandung lembaran serat kaca jenis long chopped-strand mat akan memiliki sifat-sifat elastic yang secara makrostruktur bersifat isotropic. Sehingga efek konsentrasi tegangan pada ujungujung serat dalam penelitian ini dapat diabaikan.

Pada umumnya estimasi sifat-sifat elastis komposit berserat random berdasarkan pada pendekatan yang diperkenalkan oleh Nielsen dan Chen (1968) yang mengasumsika bahwa besarnya nilai E dapat diperoleh dengan menggunakan persamaan sebagai berikut:

$$
\mathrm{E}=2 \pi \int_{0}^{\pi / 2} E(\theta) \cdot d \theta
$$

$\mathrm{E}(\theta) \quad$ merupakan orientasi ketergantungan E pada arah yang sama dengan arah lamina dan v. Persamaan (1) kemudian dikembangkan lagi menjadi:

$$
\frac{I}{\bar{E}\left(\theta_{2}\right.}=\frac{1}{E_{\Pi}} c^{4}+\left(\frac{1}{G}-\frac{2 V_{\Pi} \alpha}{E_{\Pi}}\right) c^{2} s^{2}+\frac{1}{c_{1}} s^{4}
$$

Melalui pendekatan arah lamina, maka persamaan (2) di atas dapat lebih disederhanakan dan diuraikan menjadi dua bagian, yaitu arah sejajar lamina (П) atau tegak lurus lamina $(\perp)$, yaitu:

$$
\mathrm{E}=\frac{\mathrm{s}}{\mathrm{g}} E_{\Pi}+\frac{\mathrm{g}}{\mathrm{g}} E_{1}
$$

$$
\text { Persamaan (2) dan }
$$

berhubungan dengan distribusi serat secara acak dalam matriks. Dengan demikian sifat-sifat mekanik bahan dapat ditentukan melalui penentuan awal arah distribusi serat pada saat pembuatan kulit lamina.

Homma, H. (1999), mengusulkan sebuah persamaan sederhana untuk menentukan perkiraan modulus elastisitas bahan komposit GFRP berdasarkan nilai E pada masing-masing bahan penyusunnya. Perhitungan ini diperlihatkan pada Gbr. 1.

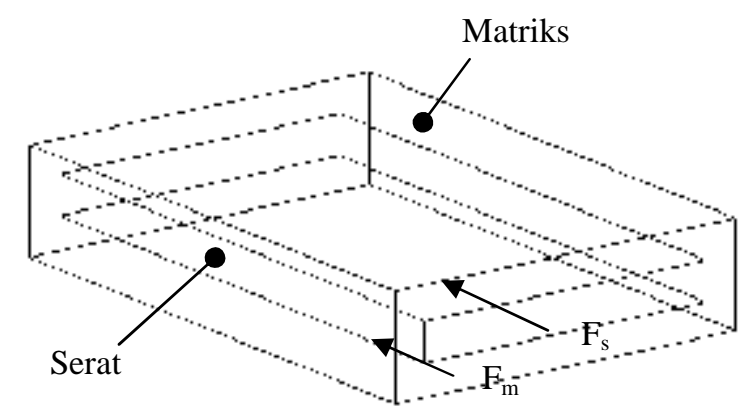

Gambar. 1. Skema pembebanan pada lamina bahan komposit GFRP. 
$\mathrm{F}_{\mathrm{m}}$ merupakan gaya yang bekerja pada matriks dan $\mathrm{F}_{\mathrm{s}}$ ialah gaya yang terjadi pada serat. Arah kedua gaya tersebut disumsikan berasal dari arah aksial spesimen seperti diperlihatkan pada gambar 1. Maka resultan kedua gaya tersebut (F) ialah:

$$
\mathrm{F}=\mathrm{F}_{\mathrm{m}}+\mathrm{F}_{\mathrm{S}}
$$

Dengan menghubungkan persamaan (4) terhadap regangan yang terjadi, dimana $\varepsilon_{\mathrm{m}}=\varepsilon_{\mathrm{s}}$, maka persamaan (4) dapat diselesaikan menjadi:

$$
\mathrm{F}=(1+\alpha) \mathrm{F}_{\mathrm{s}}
$$

dimana $\alpha$ ialah faktor perbandingan $\mathrm{F}_{\mathrm{m}} / \mathrm{F}_{\mathrm{s}}$.

\section{Dengan}

menghubungkan persamaan (5) dengan hokum Hooke pada daerah elastis, maka diperoleh harga $\mathrm{E}$ bahan komposit GFRP melalui pendekatan:

$$
\mathrm{E}=\frac{F}{\left(A_{m}+A_{s}\right)_{a}}
$$

Dengan mensubstitusikan persamaan (5) dan $\varepsilon$ ke persamaan (6), maka diperoleh hubungan yang lebih spesisfik lagi untuk nilai E, yaitu:

$$
\mathrm{E}=\frac{(1+\alpha] E_{g} A_{g}}{A_{m}+A_{g}}
$$

\section{Impak Laju Regangan Tinggi}

Pengujian ini disebut dengan pengujian impak laju regangan tinggi. Pembebanan yang diberikan pada kecepatan lebih dari $200 \mathrm{~m} / \mathrm{s}$ akan menghasilkan rambatan gelombang regangan pada spesimen yang selanjutnya akan ditangkap oleh strain gage. Data-data laju rambatan gelombang ini pada akhirnya akan menghasilkan informasi kekuatan bahan komposit yang diuji.

Pengujan ini terdiri dari 3 bagian utama, yaitu (1) batang penekan (projectile), (2) batang penerus, dan (3) spesimen uji. Susunan pengujian impak ini diperlihatan pada Gbr. 2.

$\begin{array}{ccc}\text { Batang } & \text { Batang } & \\ \text { penekan } & \text { Penerus } & \text { Spesimen }\end{array}$

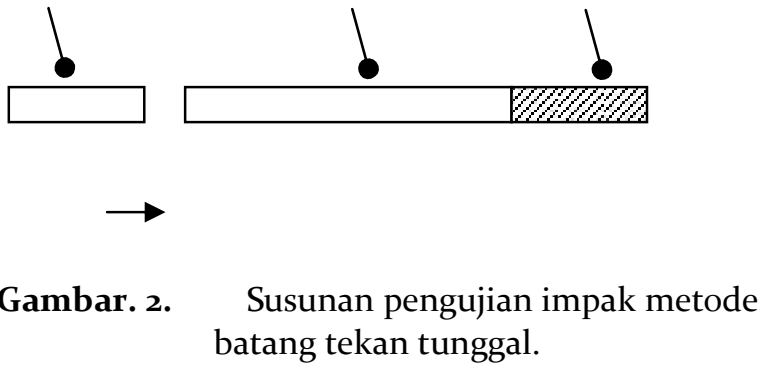

Batang penekan pada pengujian ini merupakan bahan yang bersifat isotropik yang memiliki sifat penyebaran beban ke segala arah sama rata. Sehingga skema pembebanan pada batang penekan, 
penerus, dan spesimen memiliki pola yang relatif sama. Perbedaan ketiga bagian ini ialah terletak dari kerapatan partikel sehingga menyebabkan perbedaan kecepatan rambat gelombang dalam masing-masing bagian.

Penambahan serat pada spesimen uji akan semakin meningkatkan laju rambatan gelombang regangan dalam spesimen. Hal ini menunjukkan bahwa secara mikroskopis spesimen memiliki jarak molekul yang semakin rapat. Dengan kata lain kekuatan bahan terhadap pembebanan impak juga semakin tinggi.

Fenomena rambatan gelombang regangan pada bahan isotropik akibat beban impak laju regangan tinggi diperlihatkan pada Gbr. 3.

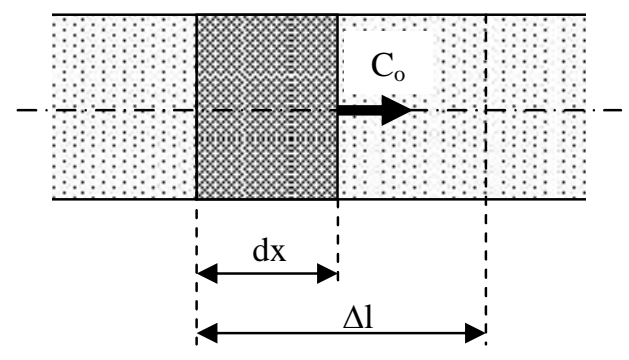

Gambar. 3. Rambatan gelombang regangan pada spesimen isotropik.

Kecepatan rambat gelombang regangan $\left(\mathrm{C}_{0}\right)$ diperoleh berdasarkan waktu yang dibutuhkan $(\Delta \mathrm{t})$ oleh suatu gelombang regangan yang merambat pada suatu panjang daerah tertentu $(\Delta \mathrm{l})$ dalam spesimen.
Anggap daerah yang mengalami gangguan regangan diasumsikan sebagai elemen ABB'A'. Maka gaya total yang terjadi pada elemen tersebut diperlihatkan pada Gbr. 4.
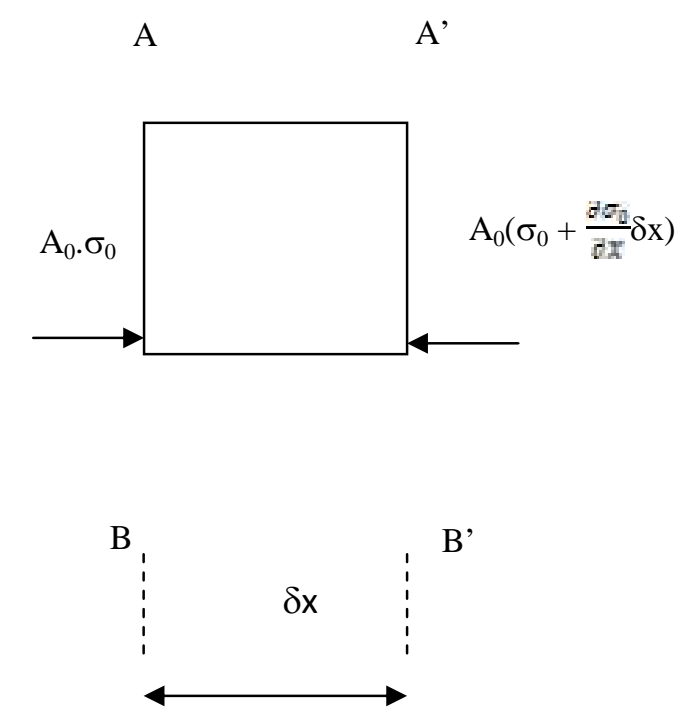

Gambar. 4. Persamaan gaya yang bekerja pada elemen yang mengalami rambatan regangan.

Setelah waktu ot dengan kecepatan gelombang awal $\mathrm{C}_{0}$, maka panjang daerah elastis yang ditempuh adalah sebesar $\mathrm{C}_{0 .}$ бt. Dengan menghubungkan terhadap kecepatan batang penekan $\left(\mathrm{V}_{0}\right)$ pada selang waktu tersebut, maka perubahan momentum yang terjadi memenuhi persamaan sebagai berikut:

$$
A_{0} \cdot \rho_{0} \cdot \delta x \cdot \frac{\partial^{2} \omega_{\alpha}}{\partial t^{2}}=\sigma_{0} \cdot A_{0}
$$

Kesetimbangan gaya pada elemen ABB'A' pada gambar 4 disusun menjadi: 


$$
-\frac{\partial \epsilon_{0}}{\partial x} \delta x \cdot A_{U}=u_{0} \cdot A_{U}
$$

Dengan mensubstitusikan persamaan (8) dan (9) diperoleh persamaan gerak untuk elemen tersebut, yaitu:

$$
\frac{\partial \sigma_{0}}{\partial x}=-\rho \frac{\partial^{2} u}{\partial x^{2}}
$$

dimana $\rho$ adalah rapat massa spesimen sebelum mengalami gelombang regangan.

Dengan menghubungkan persamaan (10) dan diferensial persamaan hukum Hooke ( $\left.\sigma_{0}=-\mathrm{E} . \mathrm{Cu} / \mathrm{cx}\right)$, maka diperoleh persamaan elastisitas:

$$
\frac{\partial^{2} u}{\partial t^{2}}=\frac{E}{p} \frac{\partial^{2} u}{\partial x^{2}}
$$

\section{Menurut Johnson}

persamaan kecepatan gelombang rambatan regangan pada medium elastis memenuhi persamaan sebagai berikut:

$$
\frac{\partial^{2} u}{\partial t^{*}}=C_{0} \frac{\partial^{2} u}{\partial x^{2}}
$$

Dengan mensubstitusikan persamaan (11) ke persamaan (12), maka diperoleh persamaan $\mathrm{E}$ bahan akibat beban impak, yaitu:

$$
E=\rho \cdot C_{0}^{2}(13)
$$

\section{METODE PENELITIAN}

Spesimen dibuat dari campuran unsaturated polyester resin dan serat GFRP. Diameter serat divariasikan mulai dari 1 $\mathrm{mm}, 3 \mathrm{~mm}, 5 \mathrm{~mm}$, dan $9 \mathrm{~mm}$. Untuk mempercepat proses pengerasan, maka pada campuran tersebut diberikan Methyl Ethyl Keton Peroxide (MEKPO) yang berfungsi sebagai katalis dengan jumlah $10 \%$ dari total volume campuran.

Spesimen dibentuk menyesuaikan dengan diameter batang penerus, yaitu sebesar 19,5 mm dengan panjang $200 \mathrm{~mm}$. Pada bagian permukaan spesimen diletakkan dua buah strain gage yang segaris dengan jarak antar strain gage 100 $\mathrm{mm}$.

Pengujian dilakukan dengan menggunakan alat uji impak AGC (Air Gun Compressor). Ujung spesimen diletakkan rapat pada ujung batang penerus dengan tujuan untuk mengurangi kehilangan beban impak yang ditransmisikan dari batang penerus ke spesimen uji.

\section{HASIL DAN PEMBAHASAN}

Data hasil pengujian diperlihatkan pada Gambar. 5. Data ini sudah diolah menjadi hubungan tegangan $(\sigma)$ yang merambat disepanjang spesimen terhadap waktu rambatan (t) ketika gelombang 
tegangan tersebut melewati susunan strain gage.

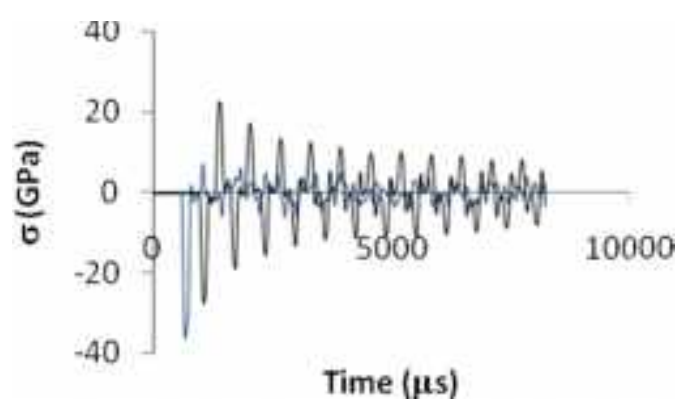

Gambar. 5. Grafik hasil pengujian impak laju gelombang regangan tinggi.

Besarnya kecepatan rambatan gelombang tegangan yang terjadi akibat beban impak dapat diketahui dengan mengukur waktu yang ditempuh gelombang tersebut untuk melewati kedua strain gage yang telah dipasang. Proses ini diperlihatkan pada Gbr. 6 dengan mengambil skala grafik pada sumbu aksis diantara $400 \mu \mathrm{s}$ sd. $1000 \mu \mathrm{s}$.

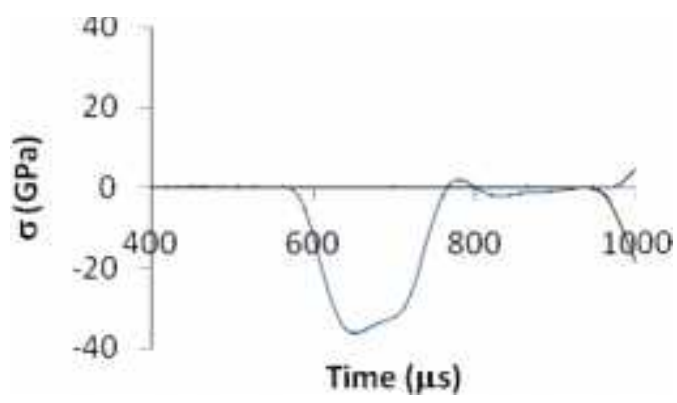

Gambar. 6. Penangkapan gelombang regangan pada kedua strain gage.

Dengan demikian nilai E bahan komposit dapat diketahui dengan menggunakan pers. (13).
Nilai E yang diperoleh merupakan nilai rata-rata pengujian terhadap 20 buah spesimen uji. Grafik sebaran nilai E (GPa) dengan variasi diameter serat diperlihatkan pada Gambar. 7 sd. 10. Standar defiasi (STD) data juga diperlihatkan.

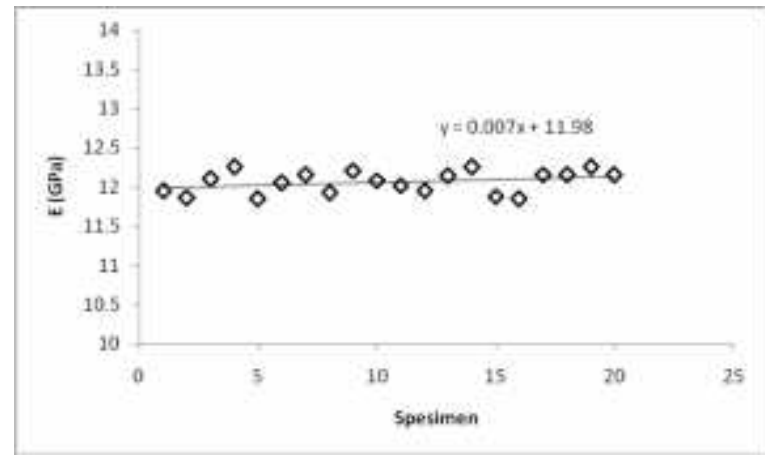

Gambar. 7. Diameter serat $1 \mathrm{~mm}(\mathrm{STD}=0,133$ $\mathrm{GPa})$.

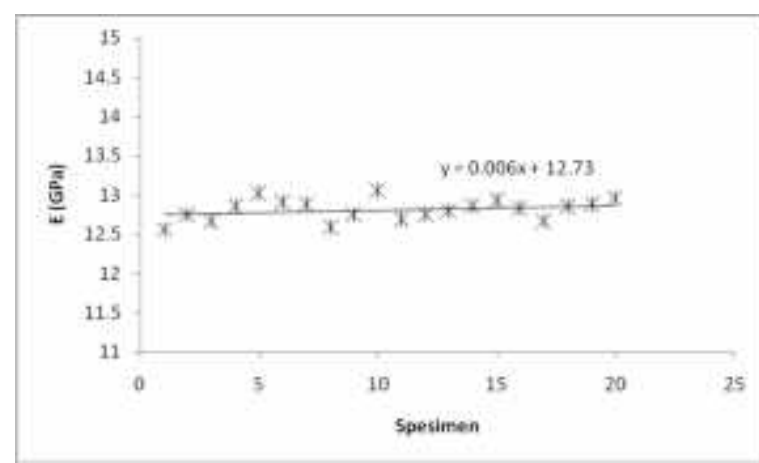

Gambar. 8. Diameter serat $3 \mathrm{~mm}(\mathrm{STD}=0,132$ $\mathrm{GPa})$.

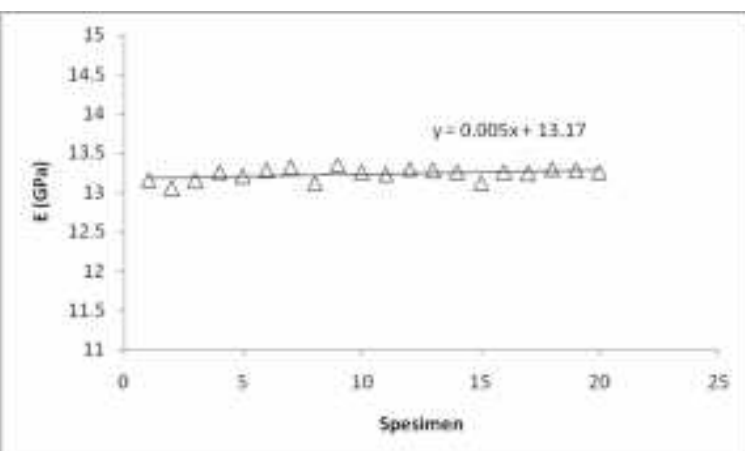


Gambar. 9. Diameter serat $5 \mathrm{~mm}(\mathrm{STD}=0,07$ GPa).

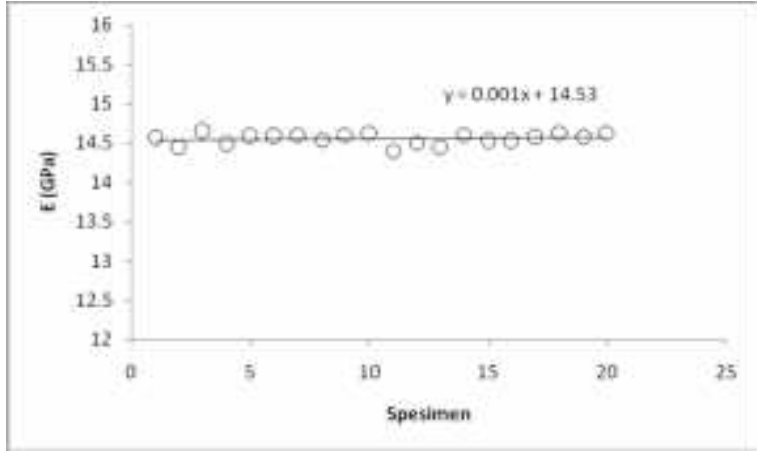

Gambar. 1o. Diameter serat $9 \mathrm{~mm}(\mathrm{STD}=0,07$ $\mathrm{GPa})$.

Berdasarkan hasil pengujian tersebut terlihat bahwa harga E rata-rata pada masing-masing variasi diameter mengalami kenaikan setiap peningkatan diameter serat dengan kenaikan rata-rata sebesar 6\%. Peningkatan harga E tersebut diperlihatkan pada Gambar. 11.

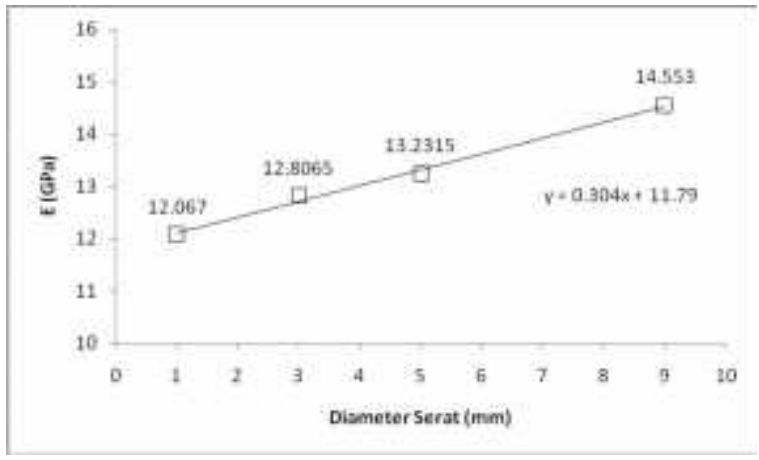

Gambar. 11. Harga E rata-rata bahan terhadap variasi diameter serat.

Berdasarkan data-data hasil pengujian terlihat bahwa peningkatan diameter serat sebanding dengan kenaikan harga E komposit GFRP. Hal ini menunjukkan bahwa penambahan serat akan mengakibatkan peningkatan ketahanan bahan terhadap deformasi yang muncul sebagai efek dari beban impak yang diberikan.

\section{SIMPULAN}

Berdasarkan serangkaian pengujian yang telah dilakukan diketahui bahwa harga E rata-rata bahan komposit sangat dipengaruhi oleh jumlah kandungan serat yang berada dalam matriks bahan tersebut. Hal ini terbukti berdasarkan hasil pengujian yang telah dikerjakan bahwa peningkatan diameter serat dalam bahan komposit GFRP akan berdampak langsung pada peningkatan harga E rata-rata ketika bahan ini diberikan beban impak laju regangan tinggi.

Bila dibandingkan dengan harga $\mathrm{E}$ rata-rata pada uji statik, yaitu sekitar 405 $\mathrm{MPa}$, maka terlihat bahwa pada kondisi dinamik bahan ini memiliki ketahanan deformasi yang lebih baik. Dengan demikian bahan komposit GFRP dapat direkomendasikan untuk pemakaian pada kondisi beban dinamik tersebut.

\section{DAFTAR PUSTAKA}

Kelly, A., 1986, Handbook of Composites: Failure Mechanics of Composites (Vol. 3), New York: Elsevier Science Publishing Company Inc.

Johnson, W., 1983, Impact Strength of Materials (2 ${ }^{\text {nd }}$ ed.), London: Edward Arnold (Publisher) Limited.

Vinson, J. R. and Sierakowski, R. L., 1990, The Behaviour of Structures Composed of 
Zulfikar, Analisa Eksperimental Modulus Elastisitas Bahan Komposit Glass Fiber Reinforced Plastic (Gfrp) ...

Composite Materials (2nd ed.), Den Haag: Klumer Academic Publishers.

Chawla, K. K., 1987, Composite Materials, Berlin: Springer-Verlag Inc.

Gibson, L.J., and Ashby, M. F., 2001, Cellular Solids: Structure and Properties (2 ${ }^{\text {nd }}$ Ed.), New York: Cambridge University Press.

Syam, B., dan Zulfikar, 1999, Modulus elastisitas Dinamik dan Statik Material Komposit GFRP (Glass Fiber Reinforced Plastic) Bentuk Plat dan Batang, Penelitian Tugas Sarjana, Tidak dipublikasikan. 